\title{
UNDANG-UNDANG NOMOR 1 TAHUN 1974 DALAM PERSPEKTIF HISTORIS-POLITIS
}

\author{
Jainuddin \\ Institut Agama Islam (IAI) Muhammadiyah Bima \\ Jln. Anggrek No. 16 Ranggo Na'e Kota Bima \\ Email: Jainuddin.ptais015@gmail.com
}

\section{Abstrak}

Undang-Undang Nomor 1 tahun 1974 merupakan wujud dari Positivisasi Hukum Islam di Indonesia. Lahirnya Undang-Undang Nomor 1 tahun 1974 merupakan salah satu upaya perjuangan politik umat islam Indonesia. Secara spesifik Undang-Undang Nomor 1 Tahun 1974 mengatur tentang hukum perkawinan yang di khususkan bagi umat islam. Tulisan ini menggunakan pendekatan Sejarah dan Politik hokum guna melihat sebuah proses Panjang sejak rancangan undang-undang ini di ajukan hingga di tetapkan menjadi sebuah Undang-Undang yang dapat dijadikan sebagai landasan hukum bagi umat islam dalam melaksanakan kehidupan beragama dalam konteks keindonesiaan.

Keywords: Undang-Undang, Historis, Politis.

\section{Pendahuluan}

Undang-Undang Dasar Negara Republik Indonesia Tahun 1945 (UUD 1945) menempati posisi tertinggi dalam hirarki peraturan di Indonesia, sehingga ia harus dijadikan sebagai sumber hukum tertinggi dalam pembentukan peraturan yang ada di bawahnya. Konsekuwensi lain adalah, secara hirarkis tidak boleh terjadi 
pertentangan antara undang-undang yang berada di bawah UUD 1945 dengan substansi UUD 1945, ${ }^{1}$ sesuai dengan stufenbau theorie yang dikenal dalam teori hukum. Hal demikian tentu saja tidak terlepas dari eksistensi UUD yang sebagaimana dikatakan oleh A. A. H Struycken dan selanjutnya dikutip oleh Dahlan Thaib bahwa UUD adalah dokumen formal yang berisi hasil perjuangan politik bangsa di masa lampau. Selain itu, UUD juga dipandang sebagai tingkat tertinggi perkembangan ketatanegaraan bangsa.

Sejak Indonesia merdeka teori receptie itu masih terasa pengaruhnya sampai dengan diundangkannya Undang-undang (UU) No.1 tahun 1974 tentang Perkawinan. Hal ini terungkap dari pasal 4 ayat 1 Peraturan Pemerintah (PP) No. 45 tahun 1957 tentang Pembentukan Mahkamah Syar'iyah di luar Jawa, Madura dan Kalimantan Selelatan/Kalimantan Timur. Dalam pasal ini dinyatakan bahwa "Mahkamah Syar'iyah memeriksa dan memutuskan perselisihan antara suami isteri yang beragama Islam dan segala perkara yang menurut hukum yang hidup diputuskan menurut hukum Islam berkenaan dengan nikah...."2

Sebenarnya hal ini merupakan problem tersendiri bagi pemerintahan Indonesia setelah bebas dari penjajahan. Belanda dengan politik hukum dan teori receptie yang diterapkanya telah membawa bangsa ini kepada pertentangan sistem hukum yang digunakan yang memang sengaja dikondisikan oleh pemerintahan Belanda waktu itu. Sehingga imbasnya masih tetap terasa di saat Indonesia telah merdeka. Sungguhpun demikian menurut Bustanul upaya kearah untuk mencari titik temu antara ketiga sistem hukum, hukum Barat (Belanda), hukum adat dan hukum Islam yang pada masa pemerintahan Hindia Belanda

1 Efik Yusdiansyah, Implikasi Keberadaan Mahkamah Konstitusi terhadap Pembentukan Hukum Nasional dalam Kerangka Negara Hukum, cet. Ke-1 (Bandung: CV. Lubuk Agung, 2010), hlm. 1.

2 Fatah Hidayat, Dinamika Perkembangan Hukum Keluarga Di Indonesia, AnNisa'a Vol. 9, No. 2, Desember 2014, hlm. 15-16

Sangaji Jurnal Pemikiran Syariah dan Hukum 
ditempatkan pada posisi yang saling bertentangan dan bertolak belakang itu tetap dilakukan.

\section{Perspektif Historis}

Lahirnya Undang-Undang Nomor 1 Tahun 1974 mengalami proses sejarah yang sangat panjang. Berawal pada tahun 1950 ketika pemerintah membentuk sebuah panitia yang diketua oleh Teuku Mohammad Hasan untuk membuat rancangan UU yang khusus mengatur tentang hukum perkawinan, talak, dan rujuk yang kemudian rancangan tersebut diselesaikan pada tahun 1952 sekalipun pada akhirnya rancangan itu gagal untuk diajukan ke DPR karena banyaknya kritik dari berbagai pihak. ${ }^{3}$ Berangkat dari kegagalan ini, panitia perancang rumusan undang-undang yang saat itu diketuai oleh Mr. Purwosutjipto dari Departemen Agama kembali menyusun undang-undang perkawinan yang bersifat khusus bagi golongan Islam, Katolik, Protestan dan lain sebagainya. Kemudian pada akhir tahun 1954, rancangan undang-undang perkawinan khusus orang islam dapat terselesaikan. ${ }^{4}$

Namun pada saat yang sama, tatkala pada tahun 1958 RUU perkawinan umat islam diajukan ke DPR secara bersamaan muncul RUU perkawinan yang berlaku secara nasional atas usulan Ny. Sumari dan kawan yang pada akhirnya kedua rancangan itu baik rancangan undang-undang perkawinan umat islam ataupun rancangan undang-undang perkawinan nasional tidak berhasil djadikan sebagai undang-undang dan dikembalikan kepada pemerintah. Kegagalan ini tidak menyurutkan langkah pemerintah untuk kembali mengajukan rancangan tentang perkawinan umat islam pada tahun 1967 walaupun kemudian pada tahun 1968 baik RUU perkawinan

3 Warkum Sumitro, Perkembangan Hukum Islam (Malang: Bayumedia Publishing, 2005), hlm. 121

${ }^{4}$ Ibid, 121 
umat islam ataupun RUU yang diajukan pemerintah mengalami nasib yang sama dengan tahun-tahun sebelumnya. Hal tersebut diakibatkan oleh penolakan fraksi Katolik yang ada di DPR-GR untuk membahas RUU yang berkaitan dengan agama. ${ }^{5}$

Pada tahun berikutnya, tepatnya pada tanggal 31 Juli 1973, rancangan undang-undang perkawinan yang pada akhirnya menjadi Undang-undang Nomor 1 Tahun 1974 diajukan oleh Presiden kepada pimpinan Dewan Perwakilan Rakyat Republik Indonesia dengan surat yang bernomor R02/P.U/VII/1973 yang sekaligus mencabut dua rancangan yang telah diajukan sebelumnya, yaitu rancangan undang-undang tentang peraturan perkawinan umat islam sebagaimana disampaikan dengan amanat presiden nomor R02/PRESS/5/1967 tanggal 22 Mei 1967 dan rancangan undang-undang tentang ketentuan-ketentuan pokok perkawinan sebagaimana disampaikan dengan amanat presiden nomor R 010/P.U/HK/9/1968 tanggal 7 September 1968. ${ }^{6}$

Sekalipun umat islam telah lama menginginkan adanya undang-undang yang mengatur tentang perkawinan, pengajuan RUU yang disampaikan oleh pemerintah justeru menuai protes yang kuat dari umat islam. ${ }^{7}$ Hal itu disebabkan oleh RUU tentang perkawinan yang diajukan pemerintah adalah RUU perkawinan nasional yang berlaku untuk semua warga negara

5 Menurut Analisis Warkum terdapat dua kemungkinan terhadap penolakan fraksi Katolik untuk membahas tentang RUU yang berkaitan dengan perkawinan islam. Kemungkinan pertama, penolakan mereka adalah terkait dengan positivisasi hukum islam, sedangkan kemungkinan yang kedua, mereka tidak menginginkan umat islam memiliki undang-undang tentang perkawinan. Padahal untuk orang katolik/kristen telah memiliki ordonansi perkawinan kristen Indonesia yang dibuat oleh pemerintah hindia-belanda pada tahun 1933, sedangkan untuk orang cina yang beragama kristen di Indonesia telah diatur oleh hukum perdata barat sejak tahun 1917.

6 Jazuni, Legislasi Hukum Islam di Indonesia (Bandung: PT. Citra Aditya Bakti, 2005), hlm. 360

7 Achmad Gunaryo, Pergumulan Politik dan Hukum Islam (Yogyakarta: Pustaka Pelajar, 2006), hlm. 132

Sangaji Jurnal Pemikiran Syariah dan Hukum 
dan disinyalir rancangan itu bercirikan sekuler ${ }^{8}$ dan bahkan secara ekstrim terdapat tuduhan bahwa RUU tersebut sengaja dibuat untuk mengkristenkan indonesia sehingga secara provokatif, Buya Hamka memfatwakan keharaman untuk mengikuti RUU perkawinan yang diajukan oleh pemerintah dan barang siapa yang masih tetap melaksanakan RUU tersebut maka ia adalah kafir. ${ }^{9}$

Terkait dengan jumlah pasal dalam RUU versi pemerintah yang dianggap bertentangan dengan ajaran islam terdapat perbedaan di kalangan para peneliti. Menurut Kamal Hasan sedikitnya terdapat 11 pasal yang dianggap bertentangan dengan ajaran islam, yaitu pasal 2 ayat 1, pasal 3 ayat 2, pasal 7 ayat 1, pasal 8 butir c, pasal 10 ayat 2, pasal 11 ayat 2, pasal 12, pasal 13 ayat 1 dan 2, pasal 37, pasal 46 huruf c dan d, pasal 62 ayat 2 dan 9. ${ }^{10}$ Berbeda dengan hasil penelitian Yusuf Hasyim yang menyebutnya terdapat 13 pasal yaitu, pasal 2 ayat 1 , pasal 3 ayat 2 , pasal 7 ayat 1 dan 2, pasal 8, pasal 10 ayat 2, pasal 11 ayat 2, pasal 12 ayat 1 , pasal 13 ayat 1 dan 2 , pasal 37 ayat 1 , pasal 39, pasal 46 butir c dan d, pasal 49 dan pasal 62. ${ }^{11}$

Adanya pasal-pasal yang dianggap bertentangan ini dan sekaligus menyulut pertentangan dan protes keras dari umat islam maka menghadapi situasi genting ini, bagi pemerintah kompromi adalah jalan terbaik mengingat dalam kondisi demikian ini stabilitas negara sedang dipertaruhkan dan bahwa tanpa adanya amandemen terhadap RUU perkawinan itu akan menyebabkan ketidakstabilan politik dan sosial. ${ }^{12}$ Langkah yang ditempuh untuk mencapai titik temu, dalam hal ini menteri agama, Mukti Ali, berinisiatif untuk melakukan

8 Warkum Sumitro, Perkembangan..., hlm. 123

${ }_{9}$ Achmad Gunaryo, Pergumulan...., hlm. 134

10 Kamal Hasan, Modernisasi Indonesia: Respon Cendekiawan Muslim (Jakarta: Lingkaran Studi Indonesia, 1987), hlm, 190

11 Achmad Gunaryo, Pergumulan...., hlm. 134

12 Ibid, hlm. 142 
lobbying antar fraksi. Karena bagi Mukti, pemerintah tidak bermaksud untuk membentuk undang-undang perkawinan yang melanggar nilai, cita, dan norma-norma agama dan pemerintah pun tidak pernah berfikir untuk memaksakan kehendak tanpa peluang bagi perbaikan dan penyempurnaan RUU yang telah diajukan. ${ }^{13}$

Melalui lobi-lobi antara tokoh agama dengan pihak pemerintah akhirnya tercapai satu kesepakatan khususnya antara fraksi Persatuan Pembangunan dan Fraksi ABRI yang isinya adalah sebagai berikut: ${ }^{14}$

a. Hukum agama islam dalam perkawinan tidak akan dikurangi atau diubah

b. Sebagai konsekuensi dari poin 1 maka alat-alat pelaksanaannya tidak akan dikurangi ataupun diubah, tegasnya UndangUndang Nomor 22 Tahun 1946 tentang Pencatatan Nikah, Nikah, Talak dan Rujuk serta Undang-Undang Nomor 14 Tahun 1970 tentang Ketentuan-Ketentuan Pokok Kekuasaan Kehakiman dijamin kelangsungannya

c. Hal-hal yang bertentangan dengan agama islam dan tidak mungkin disesuaikan dengan undang-undang ini maka akan dihilangkan

d. Pasal 2 ayat (1) dari RUUP disetujui untuk dirumuskan dengan: perkawinan adalah sah apabila dilakukan menurut hukum agamanya dan kepercayaannya itu (ayat 1) dan tiaptiap perkawinan wajib dicatat demi ketertiban administrasi negara (ayat 2)

e. Mengenai perceraian dan poligami diusahakan perlu ketentuan-ketentuan guna mencegah terjadinya kesewenang-

${ }^{13}$ Jazuni, Legislasi..., hlm. 370.

14 Rachmadi Usman, Perkembangan Hukum Perdata (Jakarta: Pustaka Sinar Harapan, 2003), hlm. 196

Sangaji Jurnal Pemikiran Syariah dan Hukum 
wenangan.

Setelah tercapai kesepakatan, akhirnya RUUP disahkan sebagai undang- undang yang diundangkan pada tanggal 02 Januari 1974 -Tambahan Lembaran Negara RI 1974 Nomor 1 dan kemudian disusul dengan lahirnya peraturan pemerintah pada tanggal 01 April 1975 sehingga praktis Undang-Undang Nomor 1 Tahun 1974 berlaku secara efektif sejak tanggal 01 oktober $1975 .{ }^{15}$ Adanya jarak waktu hampir dua tahun antara disahkannya sebagai undang-undang dan keberlakuannya secara efektif disebabkan adanya langkah-langkah persiapan dan serangkaian petunjuk-petunjuk pelaksanaan sehingga segala sesuatunya yang berkaitan dengan pelaksanaan Undang-Undang Nomor 1 Tahun 1974 dapat terlaksana dengan baik. ${ }^{16}$

Satu hal yang dapat dipahami dari tarik ulur yang pada akhirnya tercapai sebuah kesepakatan sebagaimana terlihat dalam bahasan di atas bahwa nilai-nilai keislaman dapat diletakkan sebagai representasi agama serta rancangan Undang Undang Nomor 1 Tahun 1974 sebagai representasi negara telah memperlihatkan hubungan yang dapat ditelaah setidaknya melalui tiga paradigma. Pertama, paradigma yang memandang bahwa relasi agama dan negara bersifat integrated, karenanya negara merupakan lembaga politik dan sekaligus lembaga keagamaan sebagaimana dianut oleh shiah. ${ }^{17}$ Kedua, paradigma yang memandang bahwa relasi agama dan negara bersifat simbiotik yakni berhubungan secara timbal balik dan saling membutuhkan dan juga saling menguntungkan. Dalam hal ini, agama memerlukan negara karena dengan kekuasaan negara agama dapat berkembang sebaliknya negara membutuhkan

15 Erfaniah Zuhriah, Peradilan Agama di Indonesia: Sejarah Pemikiran dan Realita (Malang: UIN Press, 2009), hlm. 129

16 Rachmadi Usman, Perkembangan..., hlm. 199-200

17 Umi Sumbulah, ,Kontroversi dan Tipologi Pemikiran Politik Islam Ali Abdur Raziq dan Pengaruhnya bagi Wajah Demokrasi di Indonesia', dalam, Islam dan Negara Pancasila (Malang: Fakultas Shari'ah, 2012), hlm. 31 
agama karena dengannya negara akan berkembang dalam bimbingan etika dan moral. Ketiga, paradigma sekuleristik yang menolak adanya relasi agama dan negara baik secara integralistik maupun relasi secara simbiotik.

Selain itu, dari rangkaian historis di atas juga terlihat bahwa RUU Perkawinan yang selanjutnya disahkan menjadi UndangUndang berkisar antara tahun 1973 sebagai pengajuan yang kemudian disetujui untuk dibahas lebih lanjut kemudian pada tahun 1974 rancangan itu disahkan menjadi undang-undang dan selanjutnya pada tahun 1975 Undang-Undang Perkawinan telah berlaku secara efektif. Dengan demikian, jika dikaji secara historis, kisaran waktu antara 1973 hingga 1975 tergolong ke dalam era Orde Baru karena Orde ini disinyalir berawal pada tahun 1966 tepatnya dengan keluarnya surat perintah 11 Maret 1966 yang sekaligus mengakibatkan lumpuhnya dua kekuatan politik utama era Orde Lama yaitu Soekarno dan PKI ${ }^{18}$ serta berakhir pada tahun 1998 dengan tumbangnya Soeharto sebagai penguasa Orde Baru selama 32 tahun pada tanggal 21 mei 1998. ${ }^{19}$

\section{Perspektif Politik}

Dalam kajian politik, era Orde Baru (1966-1998) menurut analisa Mahfud tergolong ke dalam konfigurasi politik yang otoriter yang ditunjukkan oleh peran eksekutif yang sangat dominan, kehidupan pers dikendalikan, legislatif didirikan sebagai lembaga yang lemah karena di dalamnya telah ditanamkan peran-peran eksekutif melalui Golongan Karya dan $\mathrm{ABRI}^{20}$ sehingga hukum yang dilahirkan berkarakter konservatif atau ortodoks. Dalam hal ini, hukum bersifat positivis-

${ }_{18}$ Abdul Aziz Thaba, Islam dan Negara dalam Politik Orde Baru (Jakarta: Gema Insani Press, 1996), hlm. 185

${ }_{19}$ Marzuki Wahid dan Rumadi, Figh Madhhab Negara (Jogjakarta: LKiS, 2001), hlm. 57

20 Moh. Mahfud MD, Membangun Politik Hukum, Menegakkan Konstitusi (Jakarta: Rajawali Pers, 2011), hlm. 71

Sangaji Jurnal Pemikiran Syariah dan Hukum 
instrumentalis dan berfungsi sebagai alat ampuh bagi pelaksanaan ideologi dan program Negara. ${ }^{21}$ Selain itu, hukum yang tergolong ke dalam karakter ini cenderung kaku dan kurang tanggap terhadap tuntutan kebutuhan masyarakat serta bersifat opresif karena secara sepihak memantulkan persepsi sosial para pengambil kebijakan. Berbeda dengan konfigurasi politik yang otoriter, konfigurasi politik yang demokratis akan melahirkan produk hukum yang responsif/populistik. ${ }^{22}$ Dalam hal ini, hukum cenderung responsif terhadap tuntutan berbagai kelompok sosial dan individu di dalam masyarakatnya ${ }^{23}$ serta selalu terbuka terhadap penafsiran dalam rangka menemukan nilai-nilai tersirat yang terkandung dalam peraturan dan kebijakan. ${ }^{24}$

Kajian ini menguatkan pemahaman bahwa UndangUndang Nomor 1 Tahun 1974 merupakan produk politik dari konfigurasi politik yang otoriter, sehingga Undang-Undang Nomor 1 Tahun 1974 layak disebut sebagai undang-undang yang berkarakter ortodoks. Hal ini terlihat dari peranan masyarakat yang sangat minim dalam proses pembuatan undang-undang tersebut, sebaliknya ia dikuasai oleh pihak eksekutif terutama lembaga kepresidenan yang memiliki kewenangan terhadap hukum. ${ }^{25}$

Minimnya akses masyarakat secara umum umat islam pada

21 Abdul Hakim G. Nusantara, Politik Hukum Indonesia (Jakarta: Yayasan LBHI, 1988), hlm. 27

22 Moh. Mahfud MD, Politik Hukum di Indonesia, cet. 3 (Jakarta: Rajawali Pers, 2010), hlm. 22

${ }^{23}$ Imam Syaukani dan A. Ahsin Thohari, Dasar-Dasar Politik Hukum (Jakarta: Rajawali Pers, 2008), hlm. 77

24 Philippe Nonet dan Philip Selznick, Law and Society in Transition: Toward Responsive Law, diterjemahkan oleh Raisul Muttaqien, Hukum Responsif (Bandung: Nusamedia, 2008), hlm. 90

25 Abdul Latif dan Hasbi Ali, Politik Hukum (Jakarta: Sinar Grafika, 2010), hlm. 152-153 
khususnya terhadap pembentukan kebijakan dalam era Orde Baru mendapatkan justifikasi dari catatan Dewi Fortuna Anwar yang selanjutnya dikutip oleh Daniel Dhakidae dalam bukunya, Cendekiawan dan Kekuasaan dalam Negara Orde Baru. Dalam hal ini, Fortuna menyatakan:

"Agar diterima sepenuhnya oleh pemerintah sebagai calon politik, para pemimpin islam harus menunjukkan bahwa mereka secara politik bersifat moderat dan bahwa mereka pada umumnya menunjang ideologi dan politik pemerintah. Namun dengan berbuat demikian, orang-orang ini kehilangan kredibilitas di mata para pemilih mereka. Lebih-lebih lagi, PPP tidak diizinkan menggunakan himbauan agama islamnya yang khas yang menjadi dasar kehidupan partai itu sendiri" ${ }^{26}$

Pernyataan Fortuna di atas memberikan pemahaman bahwa memang paradigma pembangunan hukum rezim Soeharto cenderung memperkecil partisipasi kelompok dalam masyarakat. Jika pun ternyata ada kelompok dalam masyarakat yang terlibat dalam penentuan kebijakan Orde Baru lebih banyak dilatarbelakangi oleh politik-politik tertentu termasuk untuk mengurangi resistensi dari kelompok tertentu dalam masyarakat. ${ }^{27}$

Penilaian berbeda dikemukakan oleh Abdul Halim. Menurutnya, sekalipun Undang-Undang Nomor 1 Tahun 1974 lahir dalam konfigurasi politik yang otoriter tidaklah tergolong sebagai produk hukum yang berkarakter ortodoks melainkan produk hukum yang responsif. ${ }^{28}$ Alasan yang dikemukakan oleh Abdul Halim adalah aspek historis yang melatari lahirnya undang-undang tersebut yang sebelumnya telah mengundang reaksi keras dari kelompok umat islam. Langkah bijaksana yang ditempuh oleh Soeharto untuk menekan terjadinya penolakan

26 Daniel Dhakidae, Cendekiawan dan Kekuasaan dalam Negara Orde Baru (Jakarta: PT. Gramedia Pustaka Utama, 2003), hlm. 562

27 Abdul Latif dan Hasbi Ali, Politik, hlm. 152

${ }_{28}$ Abdul Halim, Politik Hukum Islam di Indonesia (Jakarta: Badan Litbang dan Diklat Depag RI., T.th.), hlm. 276

Sangaji Jurnal Pemikiran Syariah dan Hukum 
umat islam adalah merespon saran KH. Bisri dan KH. Masjkur dengan memberikan instruksi kepada Sumitro agar fraksi ABRI bekerjasama dengan fraksi PPP untuk menyusun kembali RUUP yang sejalan dengan aspirasi umat islam dan hal itu terbukti dengan terwujudnya RUUP baru yang selanjutnya ditetapkan sebagai Undang-Undang Nomor 1 Tahun 1974. ${ }^{29}$

Untuk mentipologikan Undang-Undang Nomor 1 Tahun 1974 ke dalam produk hukum yang responsif memang cukup beralasan, selain undang-undang tersebut mampu bertahan dalam kisaran waktu yang cukup lama yakni sejak diundangkannya pada tahun 1974 hingga kini baru dilakukan perubahan terhadap pasal 43 ayat (1), ${ }^{30}$ juga didukung oleh landasan teoretik yang menjadi sampel kajian dalam temuan Mahfud yang memilah secara kategoris antara konfigurasi politik yang otoriter dan demokratis yaitu perundang-undangan yang berkutat pada wilayah publik (hukum Pemilu, hukum Pemda dan hukum Agraria) sehingga untuk menggeneralisasikan ke dalam wilayah hukum privat (UndangUndang Nomor 1 Tahun 1974) memerlukan kajian lebih lanjut. Namun satu hal yang harus diingat, bahwa fakta historis pulalah yang menggiring pemahaman sehingga diperoleh satu kesimpulan bahwa Undang-Undang Nomor 1 Tahun 1974 tergolong sebagai produk hukum yang ortodoks.

Terlepas dari pengkategorian Undang-Undang Nomor 1 Tahun 1974 sebagai produk hukum yang ortodoks ataukah produk hukum yang responsif, Undang-undang tersebut adalah peraturan tertulis yang hanya dapat menjamin kepastian hukum sekalipun dengan ongkos yang sangat mahal yaitu adanya kesulitan untuk melakukan adaptasi terhadap perubahan yang terjadi di sekelilingnya sehingga dengan demikian perubahan

${ }^{29}$ Ibid, hlm. 276

30 Jaenal Aripin, Peradilan Agama dalam Bingkai Reformasi Hukum di Indonesia (Jakarta: Kencana, 2008), hlm.200 
hukum menjadi masalah yang penting. ${ }^{31}$ Dalam kondisi inilah penafsiran terhadap hukum tertulis menemukan urgensinya.

\section{Kesimpulan}

Dari uraian tersebut dapat disimpulkan bahwa UndangUndang Nomor 1 Tahun 1974 sebagai representasi negara telah memperlihatkan hubungan yang dapat ditelaah setidaknya melalui tiga paradigma. Pertama, paradigma yang memandang bahwa relasi agama dan negara bersifat integrated, karenanya negara merupakan lembaga politik dan sekaligus lembaga keagamaan; Kedua, paradigma yang memandang bahwa relasi agama dan negara bersifat simbiotik yakni berhubungan secara timbal balik dan saling membutuhkan dan juga saling menguntungkan. Dalam hal ini, agama memerlukan negara karena dengan kekuasaan negara agama dapat berkembang sebaliknya negara membutuhkan agama karena dengannya negara akan berkembang dalam bimbingan etika dan moral; Ketiga, paradigma sekuleristik yang menolak adanya relasi agama dan negara baik secara integralistik maupun relasi secara simbiotik.

secara historis, kisaran waktu antara 1973 hingga 1975 tergolong ke dalam era Orde Baru karena Orde ini disinyalir berawal pada tahun 1966 tepatnya dengan keluarnya surat perintah 11 Maret 1966 yang sekaligus mengakibatkan lumpuhnya dua kekuatan politik utama era Orde Lama. UndangUndang Nomor 1 Tahun 1974 merupakan produk politik dari konfigurasi politik yang otoriter, sehingga Undang-Undang Nomor 1 Tahun 1974 layak disebut sebagai undang-undang yang berkarakter ortodoks. Hal ini terlihat dari peranan masyarakat yang sangat minim dalam proses pembuatan undang-undang tersebut, sebaliknya ia dikuasai oleh pihak eksekutif terutama

31 Satjipto Rahardjo, Ilmu Hukum, cet. Ke-5 (Bandung: Citra Aditya Bakti, 2000), hlm. 191

Sangaji Jurnal Pemikiran Syariah dan Hukum 
lembaga kepresidenan yang memiliki kewenangan terhadap hukum. 


\section{Daftar Pustaka}

Efik Yusdiansyah, Implikasi Keberadaan Mahkamah Konstitusi terhadap Pembentukan Hukum Nasional dalam Kerangka Negara Hukum, cet. Ke-1 (Bandung: CV. Lubuk Agung, 2010).

Fatah Hidayat, Dinamika Perkembangan Hukum Keluarga Di Indonesia, An-Nisa'a Vol. 9, No. 2, Desember 2014.

Warkum Sumitro, Perkembangan Hukum Islam (Malang: Bayumedia Publishing, 2005).

Jazuni, Legislasi Hukum Islam di Indonesia (Bandung: PT. Citra Aditya Bakti, 2005).

Achmad Gunaryo, Pergumulan Politik dan Hukum Islam (Yogyakarta: Pustaka Pelajar, 2006).

Kamal Hasan, Modernisasi Indonesia: Respon Cendekiawan Muslim (Jakarta: Lingkaran Studi Indonesia, 1987).

Rachmadi Usman, Perkembangan Hukum Perdata (Jakarta: Pustaka Sinar Harapan, 2003).

Erfaniah Zuhriah, Peradilan Agama di Indonesia: Sejarah Pemikiran dan Realita (Malang: UIN Press, 2009).

Umi Sumbulah, ,Kontroversi dan Tipologi Pemikiran Politik Islam Ali Abdur Raziq dan Pengaruhnya bagi Wajah Demokrasi di Indonesia', dalam, Islam dan Negara Pancasila (Malang: Fakultas Shari'ah, 2012).

Abdul Aziz Thaba, Islam dan Negara dalam Politik Orde Baru (Jakarta: Gema Insani Press, 1996).

Marzuki Wahid dan Rumadi, Fiqh Madhhab Negara (Jogjakarta: LKiS, 2001).

Moh. Mahfud MD, Membangun Politik Hukum, Menegakkan Konstitusi (Jakarta: Rajawali Pers, 2011).

Abdul Hakim G. Nusantara, Politik Hukum Indonesia (Jakarta: Yayasan LBHI, 1988).

Moh. Mahfud MD, Politik Hukum di Indonesia, cet. 3 (Jakarta: Rajawali Pers, 2010).

Sangaji Jurnal Pemikiran Syariah dan Hukum 
Imam Syaukani dan A. Ahsin Thohari, Dasar-Dasar Politik Hukum (Jakarta: Rajawali Pers, 2008).

Philippe Nonet dan Philip Selznick, Law and Society in Transition: Toward Responsive Law, diterjemahkan oleh Raisul Muttaqien, Hukum Responsif (Bandung: Nusamedia, 2008).

Abdul Latif dan Hasbi Ali, Politik Hukum (Jakarta: Sinar Grafika, 2010).

Daniel Dhakidae, Cendekiawan dan Kekuasaan dalam Negara Orde Baru (Jakarta: PT. Gramedia Pustaka Utama, 2003).

Abdul Halim, Politik Hukum Islam di Indonesia (Jakarta: Badan Litbang dan Diklat Depag RI., T.th.).

Jaenal Aripin, Peradilan Agama dalam Bingkai Reformasi Hukum di Indonesia (Jakarta: Kencana, 2008).

Satjipto Rahardjo, Ilmu Hukum, cet. Ke-5 (Bandung: Citra Aditya Bakti, 2000), hlm. 191 